\title{
Development Of Education Comics Based Realistic Mathematics Education On Fraction Material
}

\author{
Arika Celsie Puji Lestari ${ }^{1}$, Rooselyna Ekawati ${ }^{2}$ \\ ${ }^{1}$ Jl. Ketintang, Jurusan Matematika, Kampus Ketintang Universitas Negeri Surabaya, Surabaya (60213), \\ arikalestari16030174020@mhs.unesa.ac.id \\ ${ }^{2}$ Jl. Ketintang, Jurusan Matematika, Kampus Ketintang Universitas Negeri Surabaya, Surabaya (60213), \\ $\underline{\text { rooselynaekawati@unesa.ac.id }}$
}

\begin{abstract}
ABSTRAK
Penelitian ini bertujuan untuk mendeskripsikan proses dan hasil dari pengembangan komik pembelajaran pecahan berdasarkan Pendekatan Realistik Maltematik yang difokuskan pada aspek validitas, kepraktisan dan efektifitas. Subyek penelitian ini adalah siswa sekolah menengah kelas 7. Penelitian ini merupakan penelitian pengembangan ADDIE yang meliputi 5 langkah pengembangan, yaitu analysis, design, development, implementation, and evaluation. Penelitian ini menunjukkan bahwa komik pembelajaran yang dikembangkan adalah valid, efektif dan dapat digunakan.
\end{abstract}

Kata Kunci: komik, matematika realistik, pecahan, ADDIE

\begin{abstract}
The research aims to describe the process and the result of the RME-based comics education on fraction material approach measured by aspects validity, practicality, and effectiveness. The subject of this research were students grade-7 junior high school. This research is development research with the five stages ADDIE model, and they are analysis, design, development, implementation, and evaluation. This research showed that RME-based comics education is valid, very practically, and effective.
\end{abstract}

Keywords: comics, realistic mathematics education, fraction, ADDIE

\section{Introduction}

Comics are one of the readings that are liked and desirable, because in story and character comics are very interesting. McCloud [1] define comics as images and other symbols that are positioned (side by side) in a certain order, aiming to provide information and achieve aesthetic (beauty) responses from the reader. Comics are expressive of art that represent a person's movements in conversation through static images. So, a comic is a story that contains pictures and greeting balloons in a side-by-side and sequential box that aims to entertain the reader. Comics can be used as a representation of "oral in writing"[2], expressed by using characters with balloons (which indicate sound 
intonation) and letters (which can indicate feelings, actions). Saraceni [3] explains that comics contain components, namely panel, gutter, word balloon, description, character, and background.

Many teacher use comics as a potential education medium to increase students interest in academics material. Educational comics are a reading that as a "bridge to foster interest in reading" student trought teacher guidance [4]. The use educational comics to develop a constuctivist-based learning environment, a learning environment that allows students to build their own knowledge. It can be concluded, that educational comics is a reading that is used to foster students' interest, motivation, and imagination in learning learning material. Observed from children's cognitive development, educational comics can overcome children's learning difficulties such as memorizing numbers, letters, formulas, and so on.

Realistic Mathematics Education (RME) is learning theory in mathematics is human activity and mathematics must be connected significantly with the context of everyday life. According to Freundental [5] say that, that there are two points of view from RME, namely mathematics is associated with reality and mathematics as human activity. First, mathematics is associated with real life, where mathematics should be close to everyday life situations for children. So, "realistic" here should relate to the problems of daily life of students in the minds of students and finally students can solve the problem by using mathematics. Second, mathematics as a human activity, where mathematics is defined as the process of reinvention by students in accordance with the mathematical process created.

Any students have difficulty understanding mathematical material, one of which is Fraction. Fractional numbers are numbers that can be expressed as $\mathrm{p} / \mathrm{q}$, with $\mathrm{p}$ and $\mathrm{q}$ are integers and $\mathrm{q} \neq 0$. The number $\mathrm{p}$ is called the numerator and the number $\mathrm{q}$ is called the denominator. Fractions can be said to be worth if the fractions have the same simplest value or form. Fraction is one the material that most students do not understand the meaning of fraction in everyday life. Then, from the sub chapter of fractions, which according to students is difficult in the sub chapter of the fraction addition. Because in addition of fractions, numbers cannot be directly added, but the denominator must first be added to.

Therefore, Research by Fadila Suciana, Ahmad Fauzan, dan Riry Sriningsih with tittle "Pengembangan Modul Berbentuk Komik Berbasis Kontekstual Untuk Pembelajaran Matematika di SMA" with subject, grade X students of SMA Negeri 2 Pariaman. The similarity of the research relevant to this research is the research on the development of comics. While the differences from research that are relevant to this research are on the material and subject. In this relevant study using linearly equation 2 variable material with the subject of high school students of class X. While in this study using fraction material with the subject of class VII junior high school students. This research will also be linked to RME. This relevant research shows the results $87,88 \%$ students interested in colored comic modules, $84.39 \%$ of colored comic modules are valid, $74.12 \%$ of student outcomes are considered very practical, and $90.91 \%$ comic modules are considered effective.

Based on the explanation above, the research want to development of Realistic Mathematics Education (RME) based education comics on fraction material. The aims of this reserach are describe how the process of development of RME based education comics on fraction material and how the result development of RME based education comics measured by aspects of validity, practically, and effectiveness. 


\section{Method}

The research method is a research and development, the model used in this research is the ADDIE development, because the model is clear steps carefully to produce the product and designed specifically for learning [6]. The subjects in this study were VIIgrade junior school students. ADDIE development model have fives steps, namely : Analysis, Design, Development, Implementation, and Evaluation [7].

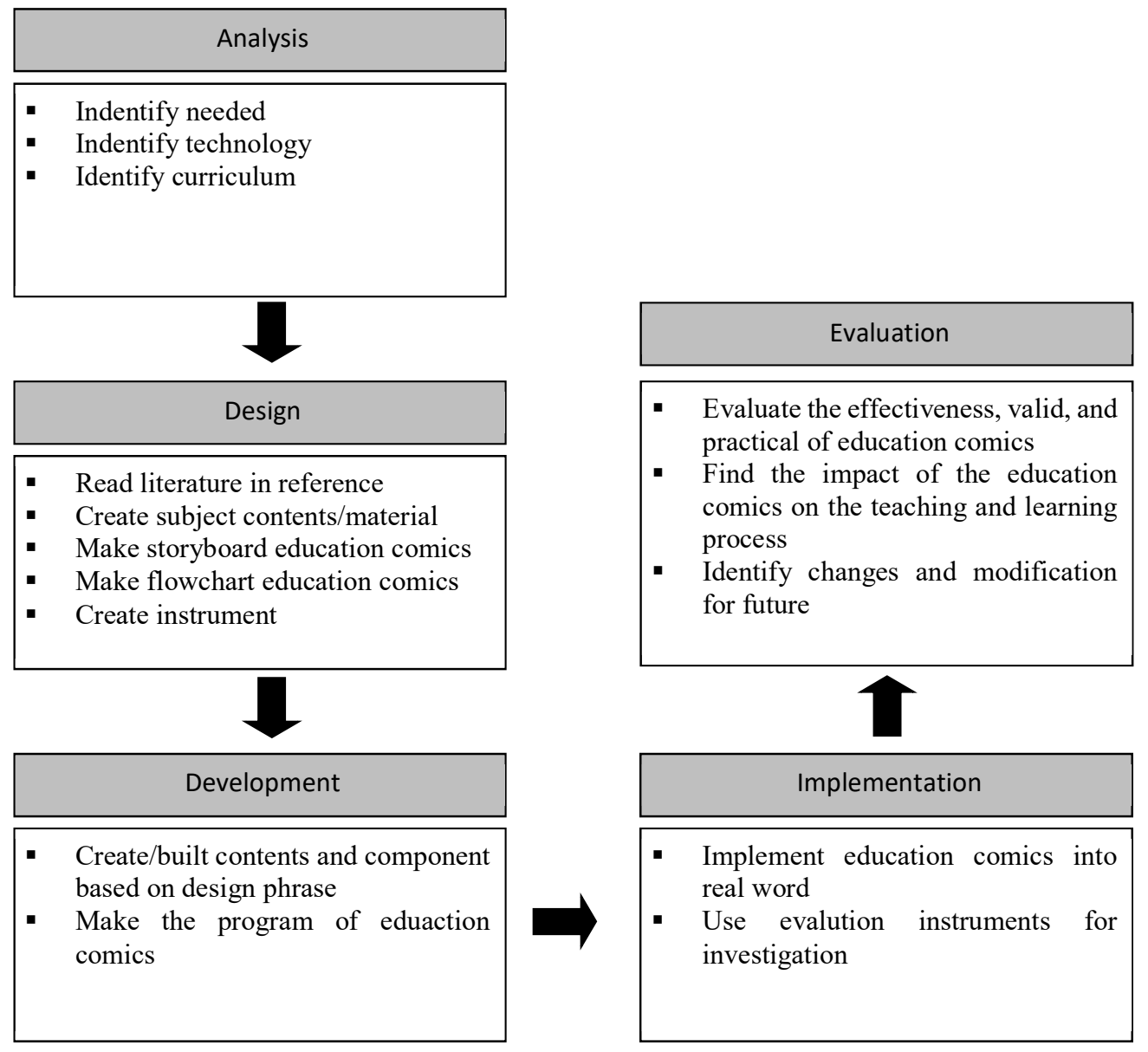

Picture 1 ADDIE models used in this study

Data collection techniques in this study used the expert test to determine validation of materials/contents expert and education comics, questionnaire given to students to determine the practically of education comics, and test learning outcomes to determine effectiveness of education comics. Nieveen [8] explain that the mean of validity, practicality, and effectiveness.

\subsection{Validity}

According to Nieveen [8] aspects of validity divided into two are the curriculum or learning model developed based on state of knowledge; and the components of the learning media are consistent related with each other. The developed education comics is 
said to be valid if the comics appropriate with theory (content validity) and the components of the education comics each other related consistently (media validity). Then, the criteria of expert validation results is

TABLE 1. Criteria of expert validation results

\begin{tabular}{ccc}
\hline \multicolumn{2}{c}{ Percentage (\%) } & Category \\
\hline 86 & 100 & Very Valid \\
\hline 70 & $\mathbf{8 6}$ & Valid \\
\hline 56 & $\mathbf{7 0}$ & Less Valid \\
\hline 0 & 56 & Invalid \\
\hline
\end{tabular}

\subsection{Practicality}

According to Nieveen [8], the measurement of practicality using the user response questionnaire with indicators that have been categorized by experts. The developed education comics is said to be practically if education comics relation to learning interests, easy of use of education comics, user interest in education comics, education comics compliance with learning, motivation, and user attention. Then, the criteria of expert pratically from questionnaire results is

TABLE 2. Criteria of Score Quesrionnaire Interpretation

\begin{tabular}{|c|c|}
\hline Percentage (\%) & Category \\
\hline $\begin{array}{ll}81 & 100\end{array}$ & Very Practical \\
\hline $\begin{array}{ll}61 & 79\end{array}$ & Practical \\
\hline 4160 & Reasonably Practical \\
\hline 2140 & Impractical \\
\hline $\begin{array}{ll}0 & 20\end{array}$ & Very Impractical \\
\hline
\end{tabular}

\subsection{Effectivity}

According to Nieveen [8], the indicator effective of product usage can be seen from student learning achievement by using the assessment instrument that is the result of learning test at the end of the learning. The developed education comics is said to be effective if education comics can make students interest to learn mathematics and help students to easy understand mathematics. Then, the criteria of expert effectiveness is

TABLE 3. Criteria of Effectiveness

\begin{tabular}{cc}
\hline Percentage (\%) & Category \\
\hline$>75 \%$ from $K K M$ & Efectiveness \\
\hline
\end{tabular}




\section{Result and discussion}

Education comics maked by comic creators. Implementation of education comics can be increase students motivation to learn mathematics. From the results of implementation education comics to 5 students grade- 7 junior high school in Surabaya showed that $100 \%$ practical and efectiveness, then $77,5 \%$ valid. Using ADDIE can be described as follows.

\subsection{Analysis}

The development of education comics has the aim of increasing students' motivation and understanding of fraction material, so that in the development of this comic requires the following stages of analysis.

a. Needed analysis

From the interview some students grade-7 junior high school, obtained they have dificulty in learning addition fraction. Then, we need something unique and interesting to increase student's motivation when they learning addition fraction.

b. Analysis technology

From the discussion with my lecture, technology or software can use to make the education comics is comic creators.

c. Analysis Curriculum

From the curriculum 2013 in Indonesia, it have "standart kompetensi", "kompetensi dasar", and indicator of fraction. The curriculum use as base of development education comic on fraction material.

\subsection{Design}

Before developing this education comics, the thing that needed to be considered was the design of the mathematical comics that would be developed. The design of education comics includes the following stages.

a. Reference

Find reference from books, journals, articles, etc. that are relevant and in according with the fraction material

b. Design of material contents

The material is designed according to competency standards, basic competencies, and fraction material indicators to be designed based on RME. The comics created by researchers help students understand fractional material, as the comics are associated with the students ' daily lives and then gradually lead to abstract fractional concepts, this is what the RME-based comics mean.

c. Story board

Design a story board to describe the storyline in education comics it appropriate with design of material contents. Writing the material script that will be made in the education comics in accordance with basic competence and indicators of achievement of fraction material competence.

\subsection{Development}


At this stage, the process of making education comics using comic creator application. Then the stage of validation by media and material experts and then revising the initial product. The analysis of education comics that have been made is related to the characteristics of the RME, namely as follows.

\subsubsection{Didactical Phenomenology}

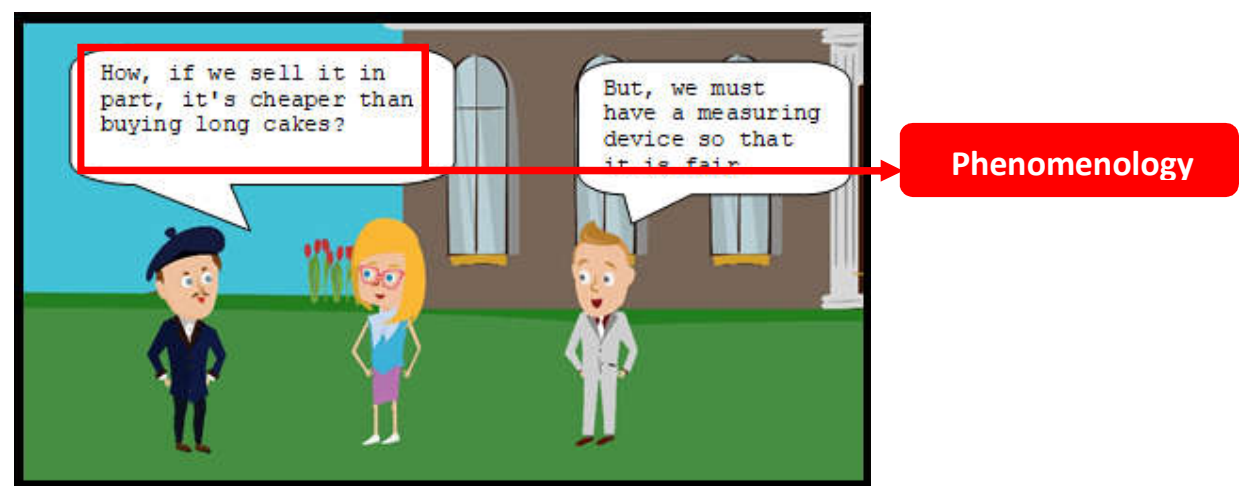

Picture 2 Part of didactical phenomenology

Education comics use close to students who can help to simulate the concept of fraction. In case, Leo Want to sell cake is part of a long cake. Then reno gives a suggestion to make a measuring instrument so that it is fair, so this problem can simulate students to think the concept of fraction.

\subsubsection{The Use of Context}

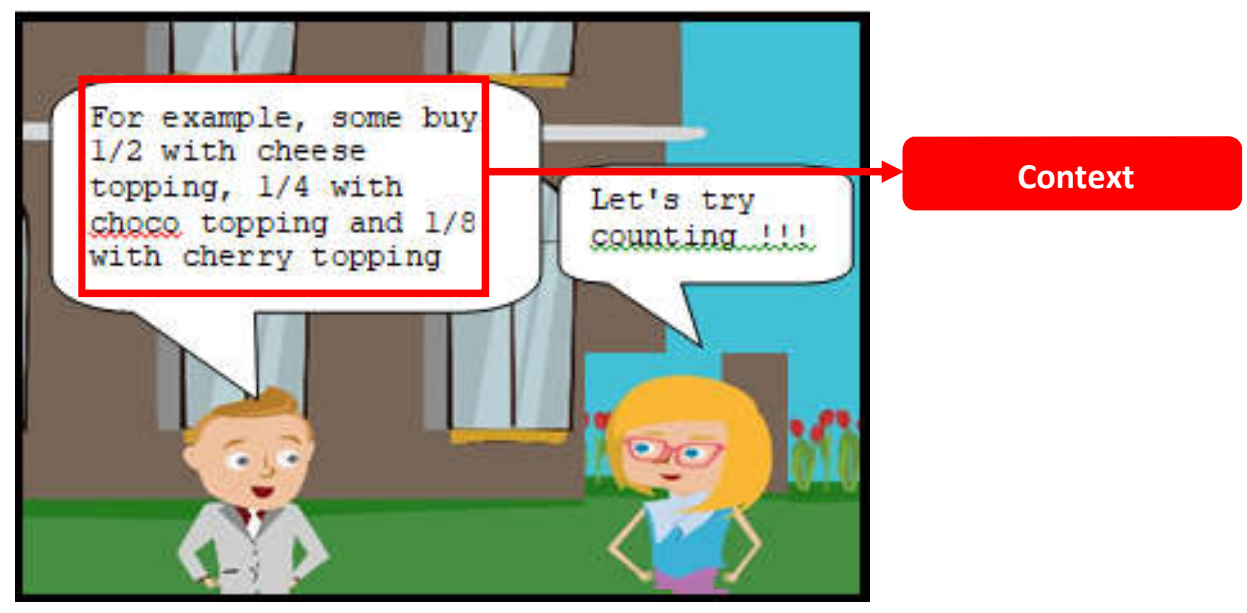

Picture 3 Part of use of context

Education comics use contextual problems. In case, Reno Want to find out the total portion of the cake from the buyer, so this problem can simulate students to find the concept of addition fraction. 


\subsubsection{The Use of Models}

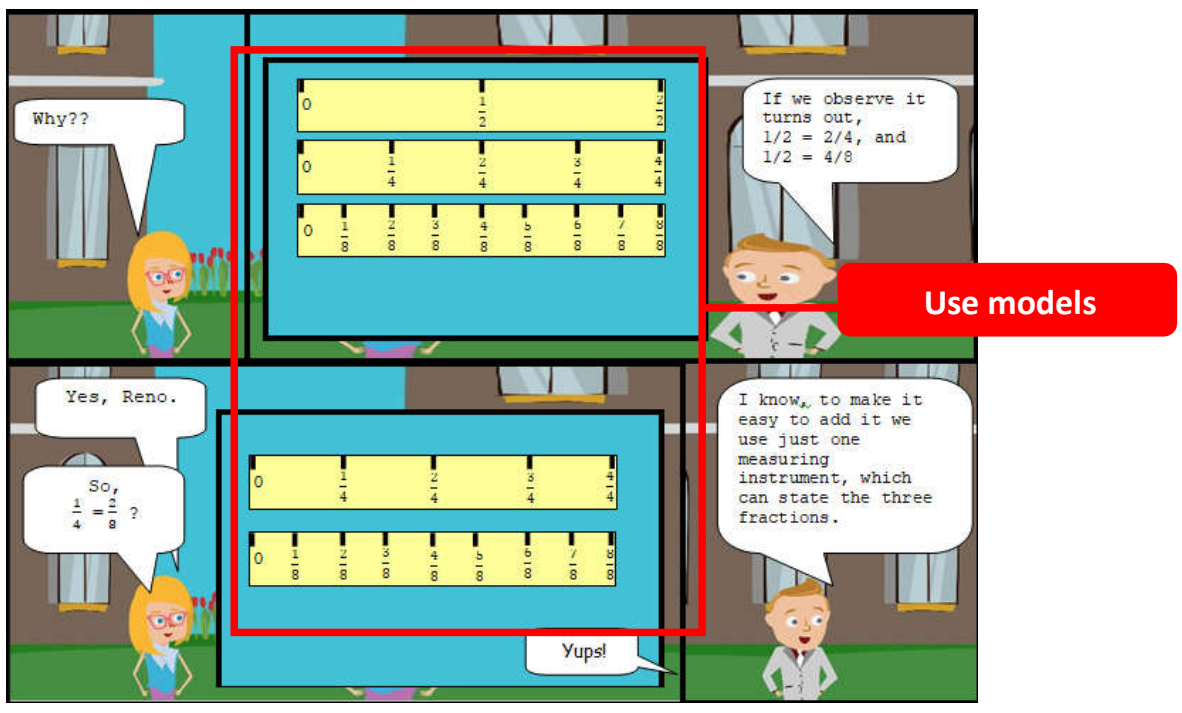

Picture 4 Part of use of models

Education comics use models, the models are measuring devices. In case, reno, leo, and laura use a measuring instrument to make it easier for them to add up the portions of bread. so in this problem can simulate students to find the concept of similarity fractions to addition fraction

\subsubsection{Guided reinvention}

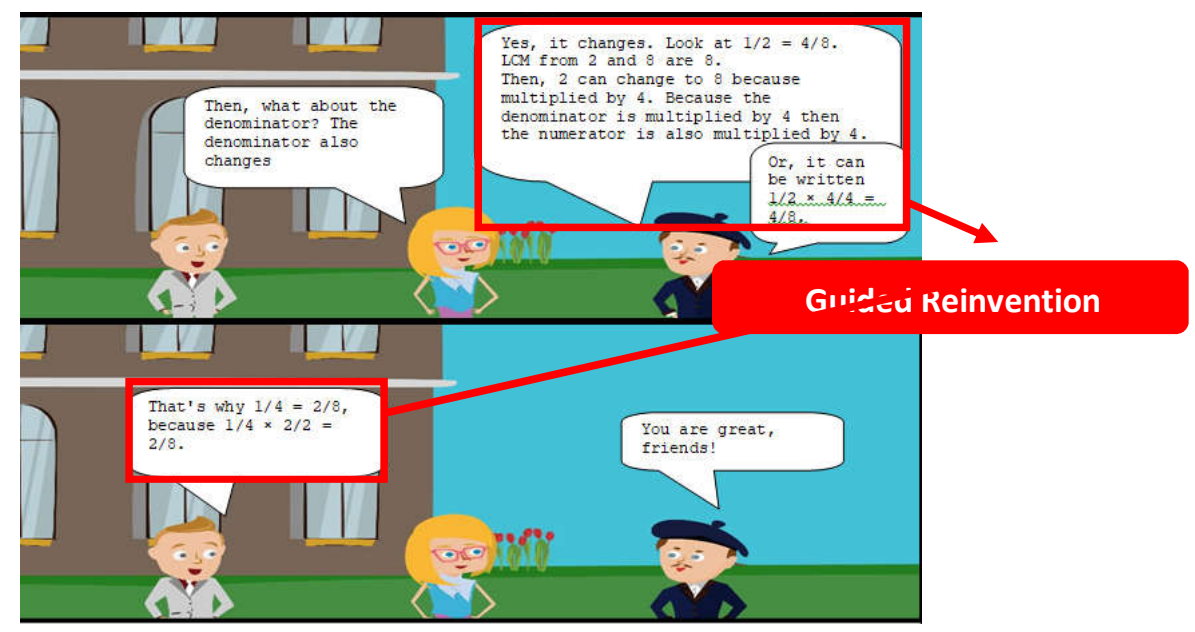

Picture 5 Part of guided reinvention 
Student reinvent addition fraction through the problem. Then, they know that the addition fraction uses similarities in fractions. And to equalize fractions of we can use concept of KPK (Kelipatan Persekutuan Terkecil).

\subsection{Implementation}

The eduaction comic that was completed, was tested to 5 junior high school in Surabaya 7 th grade students. This implementation is done to get practical and effective data from education comics.

\subsection{Evaluation}

In the evaluation stage a valid, practical and effective analysis of education comics is carried out and the second stage product revision is based on the results of the trial. Data obtained through the results of the validity questionnaire from media experts and then analyzed as above shows that the education comics developed can be categorized as valid and get $77,5 \%$. Meanwhile, data obtained through the results of the instrument test from 5 students and then analyzed as above shows that the education comics developed can be categorized as practical and get $100 \%$. After students read the education comics, and then given questions. The students easy to answer the questions, because they understand addition fraction from they read comics. So, the education comics is efectiveness and getr $100 \%$.

\section{Conclusion and Suggestion}

Based on the stages of development and research that have been tested to students and validated by experts, it can be concluded that RME-based educational comics developed get valid criteria, the practicality of RME-based educational comics has very practical criteria according to students, and the effectiveness of known educational comics through

effective learning outcomes to increase student learning outcomes. From the three categories above, educational comics can be said to be good learning media for learning.

\section{Aknowledgement}

Writing this article is inseparable from guidance and very meaningful assistance from various parties. Researcher thank the supervisor Rooselyna Ekawati, Ph.D, seventh grade students in junior high school in Surabaya, and 2016 U classmates

\section{Reference}

[1] McCloud, S., 1993. Understanding Comics. Kitchen Sink Press Inc., Nothampton, MA.

[2] Ramos, P. 2006. É Possível Ensinar Oralidade Usando Histórias Em Quadrinhos?. Revista Intercâmbio, XV, São Paulo, LAEL/PUC-SP.

[3] Saraceni, M. 2003. The Language Of Comics. London: Routledge

[4] Rohani, Ahmad. 1997. Media Intruksional Edukatif. Jakarta: PT. Rineka Cipta. Hal 79.

[5] Freudenthal, H. 1991. Revisiting Mathematics Education. China Lectures. Dordrecht: Kluwer Academic Publishers. 
Development Of Education Comics Based Realistic Mathematics Education On Fraction Material

[6] Lee, W.M dan Owen, D.L. 2004. Multimedia Based Instructional Design. San Francisco: Pfeiffer.

[7] McGriff, S.J. 2000. Instructional system design (ISD): Using ADDIE model. Retrived August $\quad 08$, 2019 from http://www.personal.psu.edu/faculty/s/j/sjm256/portfolio/kbase/IDD/ADDIE.pdf

[8] Nieveen, N. 1999. Prototyping to Reach Product Quality. Design Approaches and Tools in Education and Training, 125, (Online), (https://books.google.co.id, accessed on August 08 ${ }^{\text {rd }}, 2019$ ). 